\title{
Simulation of Carbon Dioxide Capture for Aluminium Production Process
}

\author{
Udara S. P. R. Arachchige, Dinesh Kawan, and Morten C. Melaaen
}

\begin{abstract}
A carbon capture process model was developed for the flue gas from aluminium production process. There are four different cases, which were considered for the simulation studies in Aspen Plus process simulation tool. Several $\mathrm{CO}_{2}$ concentrations, 3, 4, 7 and $10 \mathrm{vol} \%$, in the flue gas from the aluminium production is investigated. The required re-generation energy in the stripper section is in the range of 3.0 - $3.5 \mathrm{MJ} / \mathrm{kg} \mathrm{CO}$ for $85 \%$ removal efficiency and $3.2-3.5 \mathrm{MJ} / \mathrm{kg}$ $\mathrm{CO}_{2}$ for $90 \%$ removal efficiency and $3.4-3.6 \mathrm{MJ} / \mathrm{kg} \mathrm{CO}_{2}$ for $95 \%$ removal efficiency. It can be clearly seen that, (58-65)\%, $(67-75) \%,(61-67) \%$ and $(52-60) \%$ of energy requirement of case I, II, III and IV $\left(3 \%, 4 \%, 7 \%\right.$ and $10 \%$ of $\mathrm{CO}_{2}$ in the flue gas) can be replaced by available heat for replacing the re-generation process. According to the present study, it can be stated that, $4 \% \mathrm{CO}_{2}$ content in the flue gas is given the optimum available heat to replace the maximum amount of energy requirement in re-generation process.
\end{abstract}

Index Terms-Aluminium, carbon capture, flue gas, post combustion, re-boiler duty.

\section{INTRODUCTION}

The level of green house gases in the atmosphere has rapidly risen after the industrial revolution. The principle gases associated with climate change are considered as carbon dioxide $\left(\mathrm{CO}_{2}\right)$, methane $\left(\mathrm{CH}_{4}\right)$, and nitrous oxide $\left(\mathrm{N}_{2} \mathrm{O}\right)$, which accounts for $99 \%$ of global green house gas (GHG) emissions in the atmosphere [1]. Carbon dioxide is considered as the main green house gas due to the huge amount of emission to the atmosphere. The global concentration of $\mathrm{CO}_{2}$ in the atmosphere has been approximately increased from 280 parts per million by volume (ppmv) in 1830 to $316 \mathrm{ppmv}$ in 1958, and then rapidly increased to 369 ppmv in 2005 and predicted to be increased to $750 \mathrm{ppmv}$ in 2100 if there will not be any action taken in to consideration [2].

Stabilizing the concentration of atmospheric acid gases, mainly carbon dioxide $\left(\mathrm{CO}_{2}\right)$ will require massive reduction in $\mathrm{CO}_{2}$ emissions from flue gases. Alternative fuels that produce less carbon or no carbon will take several decades to reach to fulfill the demand of energy requirement. Carbon capture and sequestration (CCS) are the only means of reducing $\mathrm{CO}_{2}$ emissions in the near term future. The leading carbon emitting sources can be defined as large scale electrical power generating plants (coal and gas fired power plants) and process industries (cement, steel, aluminum, etc.) [1].

Manuscript received September 20, 2013; revised November 28, 2013.

The authors are with the the Telemark University College, Porsgrunn, Norway (e-mail: udara.s.p.arachchige@hit.no, kawandinesh@gmail.com, Morten.C.Melaaen@hit.no).
However, $\mathrm{CO}_{2}$ capturing technologies require a substantial amount of energy to isolate the captured $\mathrm{CO}_{2}$. The energy required for separation of flue gases lowers the overall efficiency of the power generating process or production process. Therefore, reduction of energy penalty for $\mathrm{CO}_{2}$ capture process is prime importance to implement the technology in industrial applications.

The basic idea behind this study is to develop and implement the $\mathrm{CO}_{2}$ capture model for flue gas from aluminium production plant. Aluminium is the second most commonly used metal in the world [3]. The most notable use of aluminium is in transportation and construction sections, and it will cover more than half of the total consumption.

The task is to find the optimal solvent concentration and lean $\mathrm{CO}_{2}$ loading to capture the $\mathrm{CO}_{2}$ from flue gas stream with lowest re-boiler energy requirement. At the same time, the most crucial parameter values regarding to carbon capture will be calculated. Flue gas properties were taken from Hydro aluminium manufacturing plant located in Norway. The $\mathrm{CO}_{2}$ capture process is going to be simulated in Aspen Plus with Monoethanolamine (MEA) as the absorption medium in the capture plant. Several $\mathrm{CO}_{2}$ concentrations, 3, 4, 7 and 10 vol\%, in the flue gas from the aluminium production will be investigated. Finally, according to the simulated results, percentage of optimum $\mathrm{CO}_{2}$ concentration in the flue gas will be concluded.

\section{Aluminium Production Process}

Aluminium compounds can be found in all types of clay, but the most useful ore that can be used to produce aluminium is bauxite. Aluminium is manufactured in two phases: the Bayer process (chemical process) and Hall-Heroult process (electrolytic process). The Bayer process is used to refine the bauxite ore to obtain aluminium oxide while the Hall-Heroult process of smelting the aluminium oxide to release pure aluminium. It takes about $4 \mathrm{~kg}$ of bauxite to produce $1 \mathrm{~kg}$ of aluminium. Flow diagram of the aluminium production is given in Fig. 1. In the first step of the process, sodium aluminate solution is produced by dissolving the already washed bauxite in caustic soda (sodium hydroxide) solution at high temperature and pressure. The sodium aluminate solution containing undissolved bauxite residues of iron, silicon and titanium. The impurities are removed by settling process and resulting clear sodium aluminate solution is transfer to a precipitator to extract particles of pure alumina. Further processing is taken to remove the chemically combined water and finally end with pure alumina. The produced alumina is dissolved in an electrolytic cryolite bath 
within a large carbon or graphite lined steel pot. An electric current is passed through the electrolyte at low voltage and high current to produce molten aluminium [4].

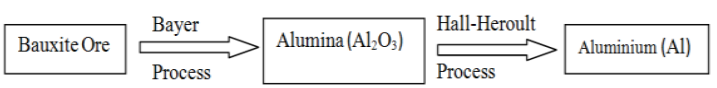

Fig. 1. Aluminium process flow diagram.

The overall chemical reaction of aluminium production is given in 1.

$$
2 \mathrm{Al}_{2} \mathrm{O}_{3}+3 \mathrm{C} \leftrightarrow 4 \mathrm{Al}+3 \mathrm{CO}_{2}
$$

Due to the melting point of the cryolitic solution, the operating temperature of the process is close to $1000^{\circ} \mathrm{C}$. To maintain the temperature rising in the cell, the process is cooled by an air flow above the cryolitic solution. Because of cooling air mixed with waste gases like $\mathrm{CO}_{2}, \mathrm{SO}_{2}$ and other impurities released from the cell, process gas is generated and transported from the cell. The waste gas components $\left(\mathrm{CO}_{2}\right.$, $\mathrm{SO}_{2}, \mathrm{HF}, \mathrm{PM}$, etc.) are removed by flue gas treatment unit before released to the atmosphere. To introduce the $\mathrm{CO}_{2}$ capture unit for aluminium production process, aluminium cell technology has to be modified. In the Hall-Heroult process illustrated in the Fig. 2, $\mathrm{CO}_{2}$ formed at the carbon anode is mixed with the cooling air supply to the system. The large volumetric air flow drop down the $\mathrm{CO}_{2}$ concentration to $1 \mathrm{vol} \%$ approximately [5].

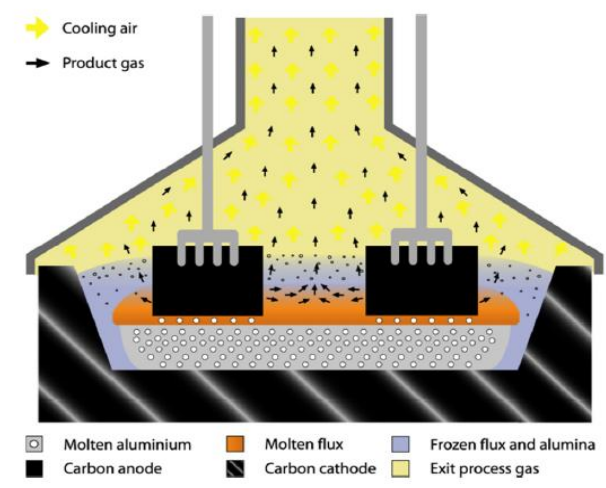

Fig. 2. Cross sectional view of the current generation of cells using the Hall-Heroult process for aluminium production [5].

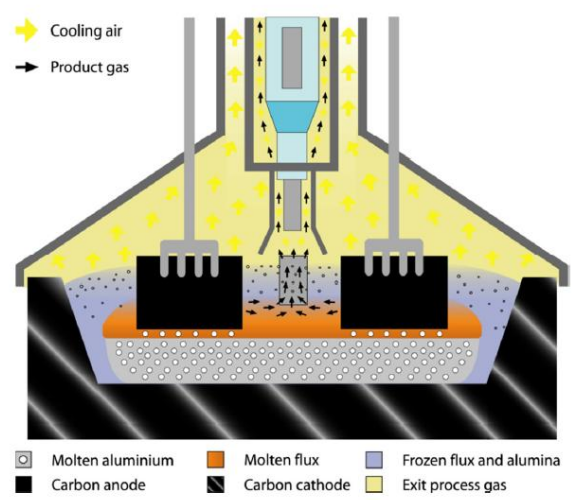

Fig. 3. Cross sectional view of the HAL Ultra cell with separate collector for product gas [5].

Due to the low $\mathrm{CO}_{2}$ concentration in the high flue gas flow rate, size of the capture plant will obviously be large, and that will be an impact on aluminium production cost. Therefore, to reduced impact on production cost, volumetric concentration of $\mathrm{CO}_{2}$ has been increased by modifying the cell in Hydro aluminium plant. The modified cell is shown in Fig. 3. As shown in the figure, new process gas collector is introduced by reducing the gas flow rate. That will reduce the total amount of process gas release to the flue gas treatment unit. This will help to increase $\mathrm{CO}_{2}$ concentration.

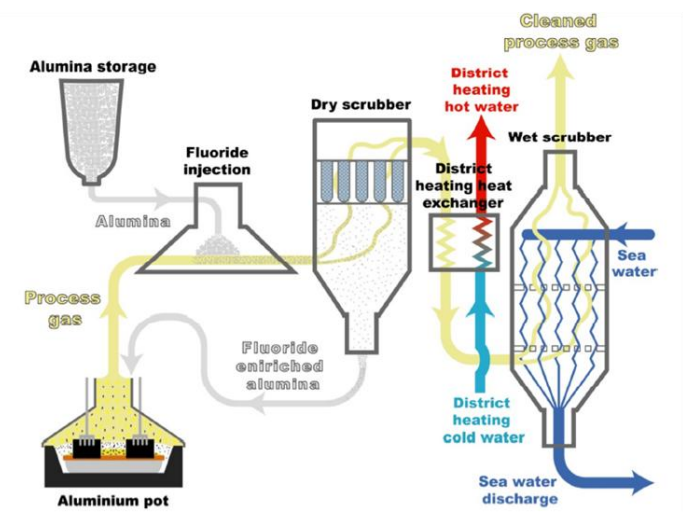

Fig. 4. The flow sheet of the process gas treatment [5]

The process gas treatment unit is in the aluminium production plant are given in the Fig. 4. It consists of several unit operation blocks to remove, $\mathrm{SO}_{2}, \mathrm{HF}, \mathrm{PM}$ and for de-dusting, as well. The cleaned gas leaving the wet scrubber can be used as an inlet of the $\mathrm{CO}_{2}$ capture unit. However, there may be some additional unit operations needed prior to the $\mathrm{CO}_{2}$ capture unit. As an example, cyclone unit to remove additional dust and additional scrubbers to remove unwanted sulphur compounds.

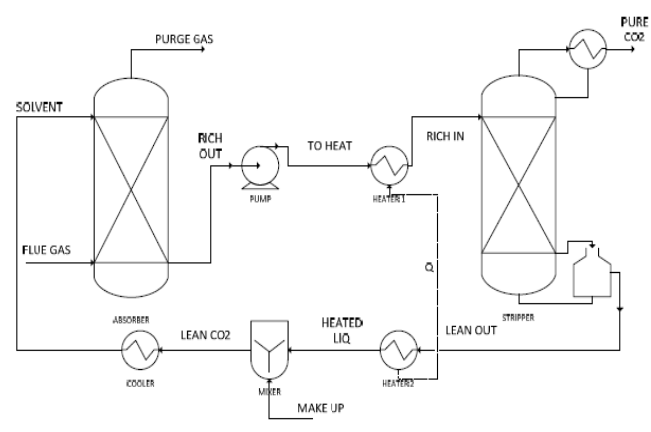

Fig. 5. Process flow diagram.

\section{MODEL DEVELOPMENT}

The main fields of environmental implications from aluminium production relates to the smelting, electrolysis and production process. The principal inputs to the aluminum smelting process can be stated as alumina, aluminum fluoride, carbon (as anodes) and electricity and the principal outputs are aluminum metal, $\mathrm{CO}_{2}$, and some solid wastes. A greenhouse gas (GHG) like $\mathrm{CO}_{2}$ is believed to contribute to climate change by increasing the ability of the atmosphere to trap heat.

According to the main chemical reaction of aluminium process, the emissions of $\mathrm{CO}_{2}$ have to be considered to maintain the environmentally friendly operation. The flue gas emission from aluminium production plant is considered for 
the simulation studies. There are four different compositions are considered to check the best $\mathrm{CO}_{2}$ content in the flue gas to be optimized for the capture process (Table I).

The basic process of $\mathrm{CO}_{2}$ capture consists of absorber and stripper units. The flue gas, which contains $\mathrm{CO}_{2}$, is flowing upward the absorber column while solvent is counter currently flowing downward. The loaded solvent is pumped to a stripping section where $\mathrm{CO}_{2}$ is generated with high temperature steam. The bottom flow of the stripper is recycling back to the absorber unit through a heat exchanger which cools the hot solvent stream and preheats the rich solvent flowing to the stripper unit. The majority of the energy demand in carbon capture process is consumed for heating the rich solvent in the stripper column. Fig. 5 shows the basic process flow diagram for post combustion carbon capture.

TABLE I: Flue GAS DATA OF ALUMINIUM PRODUCTION PROCESS

\begin{tabular}{|c|c|c|c|c|c|c|}
\hline \multicolumn{4}{|c|}{ Flue gas composition (vol \%) } & \multirow{2}{*}{$\begin{array}{l}\text { Flow rate } \\
\text { (tonnes/hr) }\end{array}$} & \multirow{2}{*}{$\begin{array}{c}\text { Temperature } \\
\left({ }^{\circ} \mathrm{C}\right)\end{array}$} & \multirow{2}{*}{$\begin{array}{c}\text { Pressure } \\
\text { (bar) }\end{array}$} \\
\hline $\mathrm{CO}_{2}$ & $\mathrm{O}_{2}$ & $\mathrm{H}_{2} \mathrm{O}$ & $\mathrm{N}_{2}$ & & & \\
\hline 3 & 20.7 & 1.0 & 75.3 & 403.6 & 225 & 1.1 \\
\hline 4 & 20.0 & 0.9 & 75.1 & 304.2 & 265 & 1.1 \\
\hline 7 & 19.4 & 0.6 & 73.0 & 176.7 & 329 & 1.1 \\
\hline 10 & 18.8 & 0.3 & 70.9 & 125.7 & 365 & 1.1 \\
\hline
\end{tabular}

TABLE II: ABSORBER PACKING DETAILS

\begin{tabular}{|c|c|c|c|c|c|c|c|c|c|c|c|c|}
\hline \multirow{3}{*}{$\mathrm{CO}_{2}$ vol\% } & \multicolumn{6}{|c|}{$\begin{array}{c}\text { Packing height in the } \\
\text { Absorber }(\mathrm{m})\end{array}$} & \multicolumn{6}{|c|}{$\begin{array}{c}\text { Packing diameter in the } \\
\text { Absorber }(\mathrm{m})\end{array}$} \\
\hline & \multicolumn{3}{|c|}{ MEA $30 \%$} & \multicolumn{3}{|c|}{ MEA $40 \%$} & \multicolumn{3}{|c|}{ MEA $30 \%$} & \multicolumn{3}{|c|}{ MEA $40 \%$} \\
\hline & $85 \%$ & $90 \%$ & $95 \%$ & $85 \%$ & $90 \%$ & $95 \%$ & $85 \%$ & $90 \%$ & $95 \%$ & $85 \%$ & $90 \%$ & $95 \%$ \\
\hline 3 & 24 & 24 & 24 & 24 & 24 & 24 & 7 & 7 & 7 & 7 & 7 & 7 \\
\hline 4 & 24 & 24 & 24 & 24 & 24 & 24 & 6 & 6 & 6 & 6 & 6 & 6 \\
\hline 7 & 24 & 24 & 24 & 24 & 24 & 24 & 4.6 & 4.6 & 4.6 & 4.6 & 4.6 & 4.6 \\
\hline 10 & 24 & 24 & 24 & 24 & 24 & 24 & 3.8 & 3.8 & 3.8 & 3.8 & 3.8 & 3.8 \\
\hline
\end{tabular}

TABLE III: SUPERFICIAL GAS VELOCITY OF ABSORBER COLUMN

\begin{tabular}{|c|c|c|c|c|}
\hline \multirow{2}{*}{} & \multicolumn{2}{|c|}{$9.5^{\circ} \mathrm{C}$ flue gas } & \multicolumn{2}{c|}{$40^{\circ} \mathrm{C}$ flue gas } \\
\cline { 2 - 5 } & Flow rate $\left(\mathrm{m}^{3} / \mathrm{hr}\right)$ & $\begin{array}{c}\text { Superficial gas velocity } \\
(\mathrm{m} / \mathrm{s})\end{array}$ & Flow rate $\left(\mathrm{m}^{3} / \mathrm{hr}\right)$ & $\begin{array}{c}\text { Superficial gas velocity } \\
(\mathrm{m} / \mathrm{s})\end{array}$ \\
\hline $3 \%$ (Case I) & 294884.7 & 2.13 & 326820.4 & 2.36 \\
\hline $4 \%$ (Case II) & 221135.7 & 2.17 & 245086.2 & 2.41 \\
\hline $7 \%($ Case III) & 128402.8 & 2.15 & 140202.9 & 2.35 \\
\hline $10 \%$ (Case IV) & 88438.13 & 2.17 & 98020.9 & 2.40 \\
\hline
\end{tabular}

The post combustion process is the well established carbon capture technology. The MEA is considered as the solvent for the capturing process. Three different solvent conditions are used to develop the process model to check most suitable operating conditions. The flow diagram of the base case process is developed with MEA concentration $30 \%$ and $40 \%$ and 0.30 (mol $\mathrm{CO}_{2} / \mathrm{mol} \mathrm{MEA}$ ) $\mathrm{CO}_{2}$ lean loading for simulation studies with $85 \%, 90 \%$, and $95 \%$ removal efficiencies. The main input parameters for development of the model is extracted from the previous studies [6], [7]. The main chemical reactions between MEA and $\mathrm{CO}_{2}$ are taken into consideration [8] with available thermodynamic and kinetic data [9].

The packing material and parameters related to packing section are considered for optimization. The packing height and diameter are varied to find the optimum packing conditions which give lowest re-boiler energy demand. The Mellapak-Sulzer $350 \mathrm{Y}$ for absorber and Flexipak-1Y for stripper are selected according to the previous studies [10]. The optimum packing conditions for the absorber column for the base case simulations is selected according to the simulation results which gives lowest re-boiler duty (in Table II). However, superficial gas velocity also considered while selecting the optimum packing dimensions to avoid flooding.

While selecting absorber diameter, superficial gas velocity is taken into consideration. The superficial gas velocity is managed to keep around 2-3 m/s. The calculated superficial gas velocity according to the selected diameter is given in the Table III.

\section{Simulations}

Simulations are performed to determine the $\mathrm{CO}_{2}$ loading effect on re-boiler duty for all four cases. The $\mathrm{CO}_{2}$ loading is varied from $0.15-0.35$ (mol $\mathrm{CO}_{2} / \mathrm{mol} \mathrm{MEA)} \mathrm{with} \mathrm{MEA}$ concentration $30 \%$ and $40 \%$. Carbon capture models are simulated for 3 different efficiencies, $85 \%, 90 \%$ and $95 \%$. The temperature of the flue gas is considered as $9.5^{\circ} \mathrm{C}$ (the temperature of flue gas in the aluminium industry) for initial case and $40^{\circ} \mathrm{C}$ (most suitable temperature for gas absorption) after that.

\section{A. Flue Gas Temperature $9.5^{\circ} \mathrm{C}$}

Re-boiler duty variation with $\mathrm{CO}_{2}$ lean loading is analyzed. Fig. 6 shows re-boiler duty variation with $\mathrm{CO}_{2}$ lean loading for Case I with $85 \%$ removal efficiency. Two lines are representing the different MEA concentrations, $30 \%$ and $40 \%$. The temperature of the flue gas stream is around $9.5^{\circ} \mathrm{C}$.

According to the Fig. 6, specific energy demand in re-boiler is decreasing until a minimum is obtained. All other cases are followed a similar trend and the optimum $\mathrm{CO}_{2}$ lean loading is selected according to the minimum re-boiler energy. The MEA concentration $40 \%$ and $\mathrm{CO}_{2}$ lean loading 0.3 give 
the optimum solvent condition for $85 \%$ removal efficiency in Case I ( $3 \% \mathrm{CO}_{2}$ in flue gas).

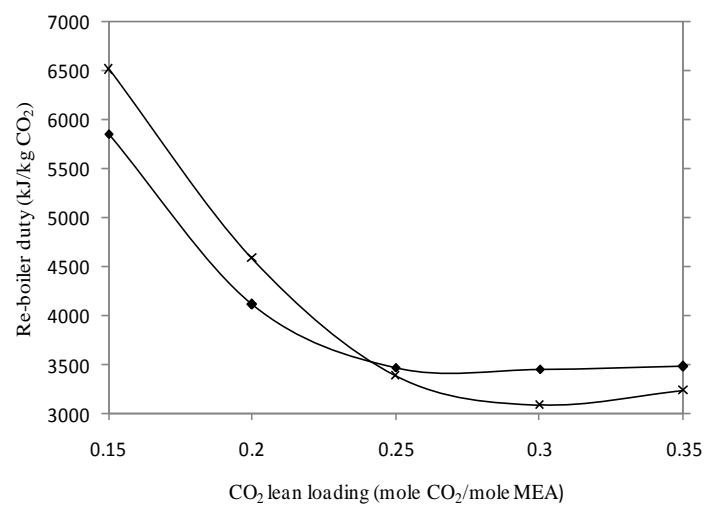

Fig. 6. Re-boiler duty variation with $\mathrm{CO}_{2}$ lean loading, symbols refer to the MEA concentrations: $\diamond, 30 ; \times, 40 \mathrm{w} / \mathrm{w} \%$.

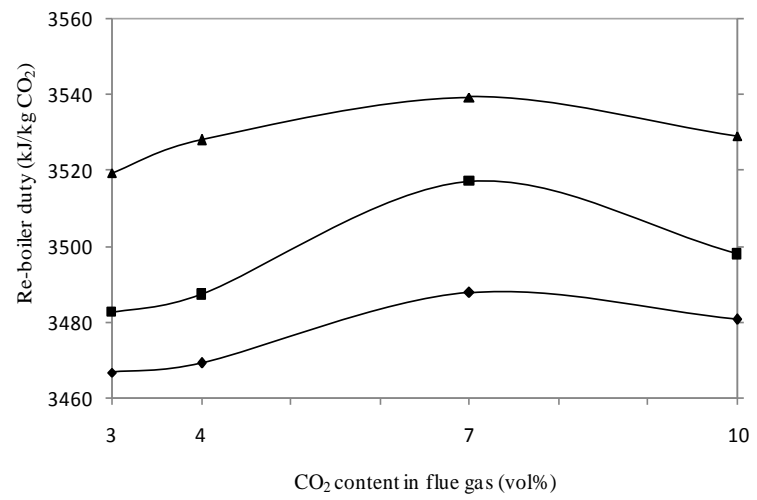

Fig. 7. Re-boiler duty variation according to the $\mathrm{CO}_{2}$ content in the flue gas for $30 \mathrm{w} / \mathrm{w} \%$ MEA concentration and $0.25(\mathrm{~mol} \mathrm{CO} 2 / \mathrm{mol} \mathrm{MEA}) \mathrm{CO}_{2}$ lean loading, symbols refer to the removal efficiency: $\bullet, 85 \%$; $\mathbf{}, 90 \% ; \boldsymbol{\Delta}, 95 \%$.

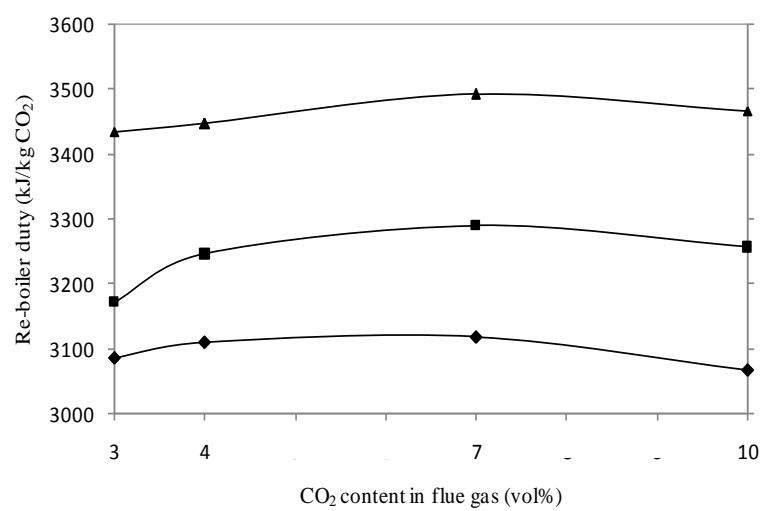

Fig. 8. Re-boiler duty variation according to the $\mathrm{CO}_{2}$ content in the flue gas for $40 \mathrm{w} / \mathrm{w} \%$ MEA concentration and $0.30(\mathrm{~mol} \mathrm{CO} 2 / \mathrm{mol} \mathrm{MEA}) \mathrm{CO}_{2}$ lean loading, symbols refer to the removal efficiency: $\bullet, 85 \%$; $\mathbf{\square}, 90 \% ; \boldsymbol{\Delta}, 95 \%$.

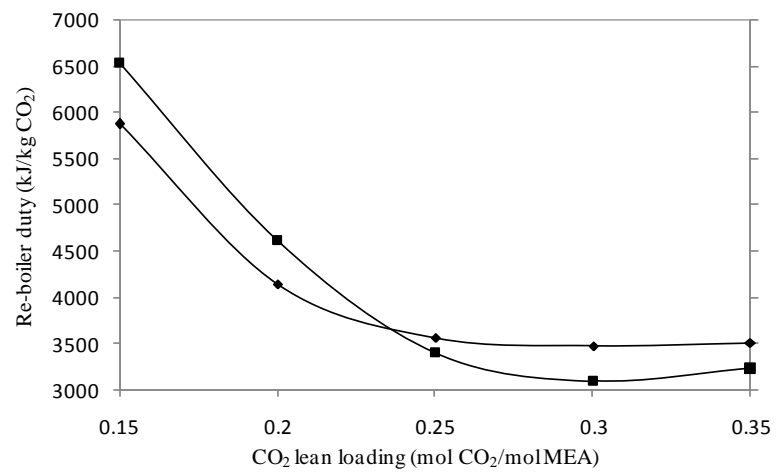

Fig. 9. Re-boiler duty variation with $\mathrm{CO}_{2}$ lean loading, symbols refer to the MEA concentrations: $\bullet, 30 ; \mathbf{m}, 40 \mathrm{w} / \mathrm{w} \%$.

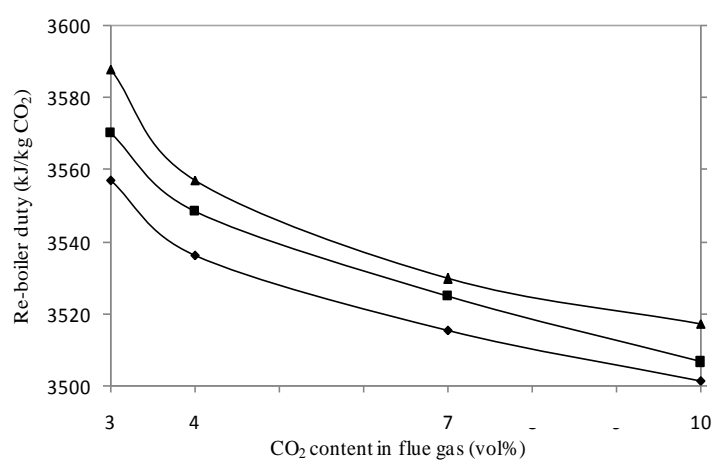

Fig. 10. Re-boiler duty variation according to the $\mathrm{CO}_{2}$ content in the flue gas for $30 \mathrm{w} / \mathrm{w} \%$ MEA concentration and $0.25(\mathrm{~mol} \mathrm{CO} / \mathrm{mol} \mathrm{MEA}) \mathrm{CO}_{2}$ lean loading, symbols refer to the removal efficiency: $\bullet, 85 \%$; $\mathbf{\bullet}, 90 \%$; $\boldsymbol{\Delta}, 95 \%$.

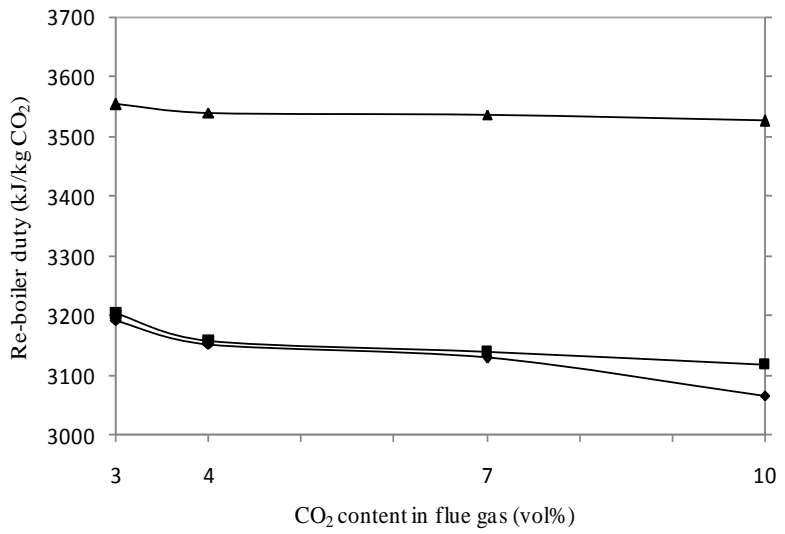

Fig. 11. Re-boiler duty variation according to the $\mathrm{CO}_{2}$ content in the flue gas for $40 \mathrm{w} / \mathrm{w} \%$ MEA concentration and $0.30(\mathrm{~mol} \mathrm{CO} / \mathrm{mol} \mathrm{MEA}) \mathrm{CO}_{2}$ lean loading, symbols refer to the removal efficiency: $\bullet, 85 \%$;, $90 \%$; $\boldsymbol{\Delta}, 95 \%$.

\section{A. Flue Gas Temperature $40^{\circ} \mathrm{C}$}

Fig. 7 and Fig. 8 represent the re-boiler duty variation according to the $\mathrm{CO}_{2}$ content in the flue gas. Figures doesn't show considerable variation according to the flue gas $\mathrm{CO}_{2}$ composition. However, $3 \% \mathrm{CO}_{2}$ content in the flue gas gives the minimum re-boiler duty compared to other cases. With the removal efficiency, re-boiler duty is increasing, and the minimum is given by $85 \%$ removal efficiency.

Similar to the previous section, simulations are performed to determine the re-boiler duty variation with lean $\mathrm{CO}_{2}$ loading. Fig. 9 shows the re-boiler duty variation with lean $\mathrm{CO}_{2}$ loading for case I (3\% CO $\mathrm{CO}_{2}$ in flue gas) with $85 \% \mathrm{CO}_{2}$ removal efficiency.

Fig. 10 and Fig. 11 represent the re-boiler duty variation according to the $\mathrm{CO}_{2}$ content in the flue gas.

Moreover, Fig. 12 illustrates the variation of the re-boiler duty with the flue gas inlet temperatures of $9.5^{\circ} \mathrm{C}$ and $40^{\circ} \mathrm{C}$ for $85 \%$ removal efficiency. It can be concluded that, specific re-boiler duty for $\mathrm{CO}_{2}$ capture process is increasing with the flue gas temperature. As can be seen from Fig.12, re-boiler energy is reducing with the $\mathrm{CO}_{2}$ content in flue gas for $40^{\circ} \mathrm{C}$ temperature case. The absorber column dimensions have a strong dependence on the specific re-boiler heat duty of the system. The optimum absorber and stripper dimensions were different for each case which has been studied due to superficial gas velocity. The absorber column dimensions can be varied slightly within the required superficial velocity range. That will again change the optimum re-boiler energy requirement for all cases. 


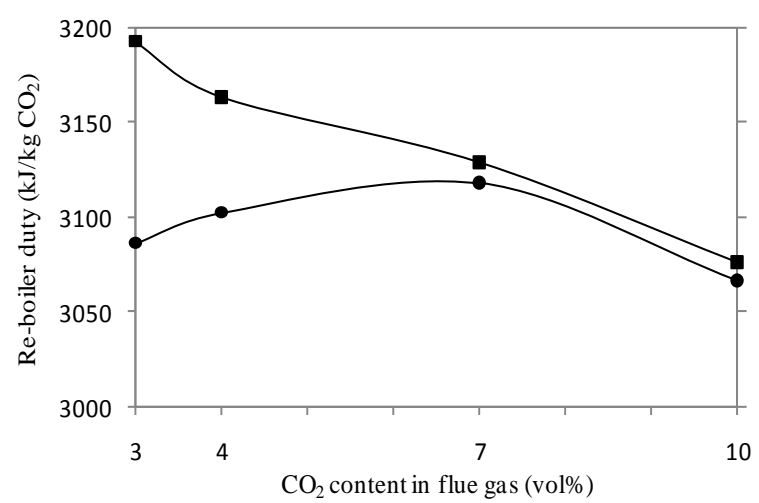

Fig. 12. Variation of the re-boiler duty with the flue gas inlet temperature, symbols refer to the flue gas temperature: $\bullet, 9.5^{\circ} \mathrm{C} ;-40^{\circ} \mathrm{C}$. (MEA concentration is $40 \mathrm{w} / \mathrm{w} \%$ and $\mathrm{CO}_{2}$ lean loading $0.30(\mathrm{~mol} \mathrm{CO} / \mathrm{mol} \mathrm{MEA} \mathrm{for}$ $85 \%$ removal efficiency).
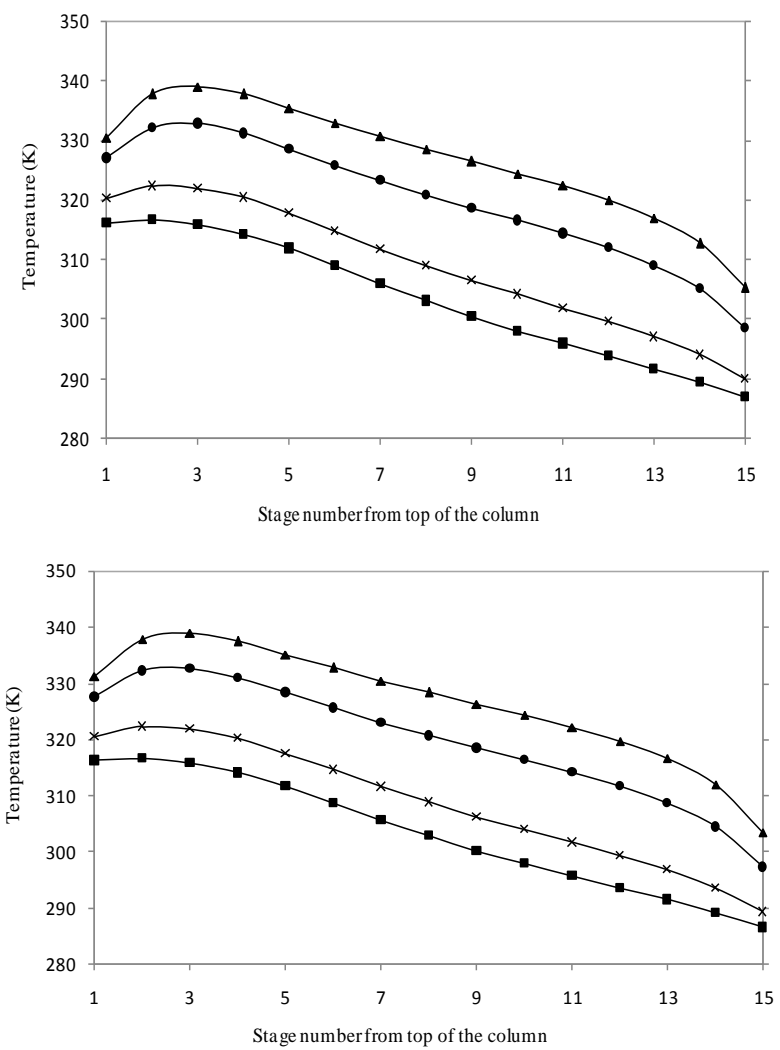

Fig. 13. Temperature profiles alone the absorption column, left hand side figure indicating liquid phase temperature and right hand side indicates vapor phase temperature for $30 \mathrm{w} / \mathrm{w} \%$ MEA concentration and $0.25(\mathrm{~mol}$ $\mathrm{CO}_{2} /$ mol MEA) $\mathrm{CO}_{2}$ lean loading with $85 \%$ removal efficiency, symbols refer to the $\mathrm{CO}_{2}$ content in the flue gas: $\mathbf{\bullet}, 3 \% ; \times, 4 \% ; \bullet, 7 \% ; \mathbf{\Lambda}, 10 \%$.

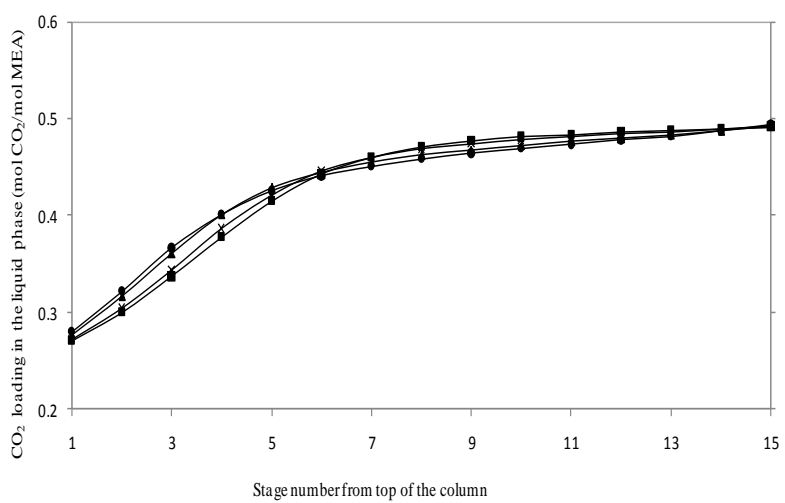

Fig. 14. $\mathrm{CO}_{2}$ loading profiles in absorber for $30 \mathrm{w} / \mathrm{w} \%$ MEA concentration and 0.25 (mol $\mathrm{CO}_{2} / \mathrm{mol} \mathrm{MEA)} \mathrm{CO}_{2}$ lean loading with $85 \%$ removal efficiency, symbols refer to the $\mathrm{CO}_{2}$ content in the flue gas: $\mathbf{\square}, 3 \% ; \times, 4 \%$; $\boldsymbol{\Lambda}$, $7 \% ; \bullet, 10 \%$
The optimum re-boiler duties for all simulation models are given in the Table IV. It can be seen from the Table IV; the re-boiler duty is increased with the removal efficiency. The reason for that is the total amount of $\mathrm{CO}_{2}$ re-generate in the stripper is high with higher removal efficiency. Therefore, the amount of solvent required to capture the $\mathrm{CO}_{2}$ in the absorption column is higher for higher efficiency. The amount of solvent will directly have an effect on re-boiler energy requirement. At the same time, the amount of $\mathrm{CO}_{2}$ content in the flue gas weakly effect on re-boiler energy. However, total amount of flue gas process in the absorption column is less with high amount of $\mathrm{CO}_{2}$ concentration in the flue gas (Case I > Case II > Case III > Case IV). Because of that the absorption column size is also reduced and it will directly effect on capital cost of the capture plant. Even though, high $\mathrm{CO}_{2}$ content (Case IV) has small impact on energy duty, it will be considerable benefit while considering the cost of capturing. Flue gas temperature has a slight impact on re-boiler energy requirement. However, higher flue gas temperature require a higher amount of energy in stripper re-generation process compare to lower flue gas temperature value. A summary of the optimum results obtained from the simulations is presented in the Table IV. Purity of the captures $\mathrm{CO}_{2}$ stream in stripper is maintained around $95 \mathrm{~mol} \%$ for every case of studies.

The $\mathrm{CO}_{2}$ capture process model is completed as a closed loop process after completing the process optimization for parameter values and solvent conditions. It can be used to calculate the required make-up stream for re-circulating back the lean solvent stream out from the stripper. The make-up stream is adjusted to fulfill water and MEA losses during the $\mathrm{CO}_{2}$ capturing process. After completing the closed loop model, temperature and the $\mathrm{CO}_{2}$ loading profiles are analyzed to study the performance of the model. Temperature profiles for Case I - IV are given in the Fig.13 for liquid and vapor phase, respectively. For profile generation, $30 \mathrm{w} / \mathrm{w} \%$ MEA concentration and $0.25 \mathrm{CO}_{2}$ lean loading is considered with $85 \% \mathrm{CO}_{2}$ removal efficiency with the flue gas temperature $9.5^{\circ} \mathrm{C}$.

From the above figure, it can be observed that the maximum liquid and vapor phase temperature inside the absorption column is around $340 \mathrm{~K}\left(67^{\circ} \mathrm{C}\right)$. Both liquid and vapor phases are following same trends. It can be conclude that $10 \% \mathrm{CO}_{2}$ gives highest temperature as $67^{\circ} \mathrm{C}$ and, $3 \% \mathrm{CO}_{2}$ gives lowest temperature value as $42^{\circ} \mathrm{C}$. All four cases illustrate the temperature bulge at the top of the column for both liquid and vapor phase. Temperature bulge is due to highly exothermic reactions at the top of the column. When the ratio between liquid $(\mathrm{L})$ and gas $(\mathrm{G})$ is relatively small, the reactions are mostly occur at the top of the column. Therefore, temperature profiles show optimum value closer to the top of the absorption column.

Furthermore, $\mathrm{CO}_{2}$ loading in the liquid phase is reached at around $0.5(\mathrm{~mol} \mathrm{CO} / 2 / \mathrm{mol} \mathrm{MEA})$ at the rich solvent stream leaving the absorption column. Fig. 14 represent the $\mathrm{CO}_{2}$ loading variation along the absorption column. All four cases follow the same trend along the column from top to bottom 


\section{HEAT INTEGRATION}

The main drawback of the $\mathrm{CO}_{2}$ capture process is high energy demand in the re-generation process. Therefore, heat integration plays a vital role in process optimization with carbon capture. The available excess heat is calculated using standard cooler block placing between the outlet of aluminium electrolyte cells and dry scrubber unit. The inlet temperature to the dry scrubber maintains around $150^{\circ} \mathrm{C}$. The heat recovery unit should be installed as shown in the Fig. 15 as proposed by previous studies [11]. The recovered heat can be used to replace part of the energy requirement in re-generation section in $\mathrm{CO}_{2}$ capture process. Additional heat has to be supplied trough separate energy plant. The flue gases generated from that energy plant will also be sent through the proposed $\mathrm{CO}_{2}$ capture section. Additional unit operations necessary prior to the $\mathrm{CO}_{2}$ capture section in order to purify the flue gas to remove dust and additional compounds.

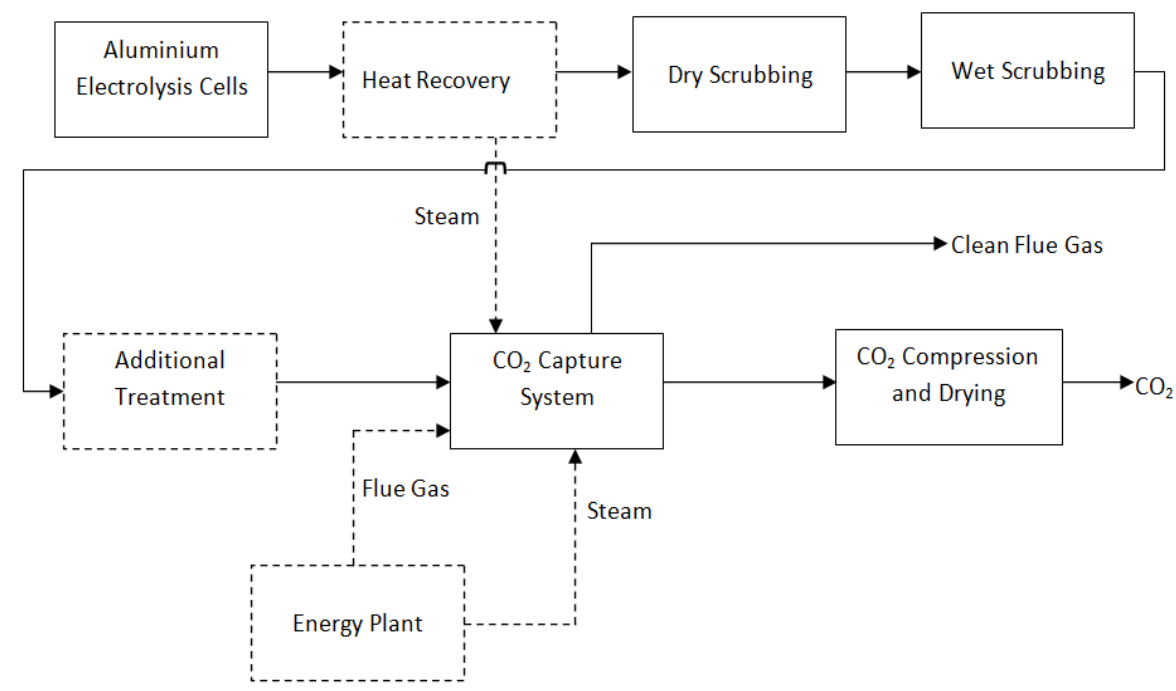

Fig. 15. Process flow diagram with heat integration section [11].

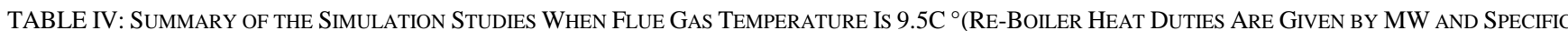
ENERGY BY KJ/KG $\mathrm{CO}_{2}$ ).

\begin{tabular}{|c|c|c|c|c|c|c|c|c|c|c|c|c|}
\hline $\mathrm{CO}_{2}$ content in the flue gas & \multicolumn{3}{|c|}{$3 \mathrm{vol} \%$} & \multicolumn{3}{|c|}{4 vol\% } & \multicolumn{3}{|c|}{7 vol\% } & \multicolumn{3}{|c|}{10 vol $\%$} \\
\hline Capture efficiency & $85 \%$ & $90 \%$ & $95 \%$ & $85 \%$ & $90 \%$ & $95 \%$ & $85 \%$ & $90 \%$ & $95 \%$ & $85 \%$ & $90 \%$ & $95 \%$ \\
\hline \multicolumn{13}{|c|}{ Re-boiler heat duty (MW) } \\
\hline $\begin{array}{l}30 \% \text { MEA and } 0.25 \mathrm{CO}_{2} \\
\text { lean loading }\end{array}$ & 14.93 & 15.88 & 16.94 & 14.94 & 15.90 & 16.98 & 15.02 & 16.22 & 16.94 & 14.99 & 15.95 & 16.89 \\
\hline $\begin{array}{c}40 \% \text { MEA and } 0.3 \mathrm{CO}_{2} \text { lean } \\
\text { loading }\end{array}$ & 13.29 & 14.46 & 15.64 & 13.39 & 14.80 & 16.07 & 13.60 & 15.01 & 16.79 & 12.99 & 14.85 & 16.45 \\
\hline \multicolumn{13}{|c|}{ Specific Re-boiler heat duty $\left(\mathrm{kJ} / \mathrm{kg} \mathrm{CO} \mathrm{CO}_{2}\right)$} \\
\hline $\begin{array}{c}30 \% \text { MEA and } 0.25 \mathrm{CO}_{2} \\
\text { lean loading }\end{array}$ & 3466 & 3482 & 3519 & 3469 & 3487 & 3528 & 3487 & 3517 & 3539 & 3480 & 3497 & 3529 \\
\hline $\begin{array}{c}40 \% \text { MEA and } 0.3 \mathrm{CO}_{2} \text { lean } \\
\text { loading }\end{array}$ & 3085 & 3171 & 3433 & 3109 & 3245 & 3446 & 3117 & 3289 & 3492 & 3066 & 3256 & 3467 \\
\hline
\end{tabular}

The calculated available excess heat in aluminium production process is tabulated with required re-generation energy. The energy requirement of $\mathrm{CO}_{2}$ capture process for the four different cases are considered. The required re-boiler duties are in the range of $3.0-3.5 \mathrm{MJ} / \mathrm{kg} \mathrm{CO}$ for $85 \%$ removal efficiency and $3.2-3.5 \mathrm{MJ} / \mathrm{kg} \mathrm{CO}_{2}$ for $90 \%$ removal efficiency and $3.4-3.6 \mathrm{MJ} / \mathrm{kg} \mathrm{CO}_{2}$ for $95 \%$ removal efficiency. If it is possible to replace part of the energy requirement using excess heat in the aluminium industry, it will be a feasible option to perform $\mathrm{CO}_{2}$ capture for aluminium flue gas processing. Depending on the $\mathrm{CO}_{2}$ content in the flue gas, the temperature of the flue gas exit the aluminium cells is different. The calculated available heat for all four cases is given in Table $\mathrm{V}$ along with the flue gas conditions.

The available heat and required heat for re-generation section is taken in to consideration. Fig. 16 and Fig. 17 present the required and available energy in aluminium production process for $\mathrm{CO}_{2}$ capturing. Fig. 16 indicates the MEA concentration $30 \mathrm{w} / \mathrm{w} \%$ and 0.25 ( $\mathrm{mol} \mathrm{CO} 2 / \mathrm{mol} \mathrm{MEA})$ $\mathrm{CO}_{2}$ lean loading and Fig. 17 for MEA concentration $40 \mathrm{w} / \mathrm{w} \%$ and $\mathrm{CO}_{2}$ lean loading $0.30(\mathrm{~mol} \mathrm{CO} / \mathrm{mol} \mathrm{MEA})$.

TABLE V: AvaIlable HeAt AND Flue Gas CONDITIONS AT DifFERENT

\begin{tabular}{|c|c|c|c|c|}
\hline $\begin{array}{c}\mathrm{CO}_{2} \\
\text { concentration } \\
(\mathrm{vol} \%)\end{array}$ & $\begin{array}{c}\text { Inlet } \\
\text { temperature } \\
\text { of the } \\
\text { energy } \\
\text { recovery } \\
\text { section }\left({ }^{\circ} \mathrm{C}\right)\end{array}$ & $\begin{array}{c}\text { Outlet } \\
\text { temperature } \\
\text { of the } \\
\text { energy } \\
\text { recovery } \\
\text { section }\left({ }^{\circ} \mathrm{C}\right)\end{array}$ & $\begin{array}{c}\text { Mass } \\
\text { flow } \\
\text { rate } \\
(\mathrm{kg} / \mathrm{s})\end{array}$ & $\begin{array}{c}\text { Available } \\
\text { heat duty } \\
(\mathrm{MW})\end{array}$ \\
\hline 3 & 225 & 150 & 112.12 & 8.69 \\
\hline 4 & 265 & 150 & 84.49 & 10.08 \\
\hline 7 & 329 & 150 & 49.09 & 9.19 \\
\hline 10 & 365 & 150 & 34.92 & 7.84 \\
\hline
\end{tabular}




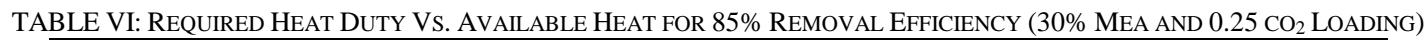

\begin{tabular}{|c|c|c|c|}
\hline $\mathrm{CO}_{2}$ concentration (vol\%) & $\begin{array}{c}\text { Required re-boiler } \\
\text { Energy (MW) }\end{array}$ & $\begin{array}{c}\text { Available heat duty } \\
\text { (MW) }\end{array}$ & $\begin{array}{c}\text { Percentage of available } \\
\text { heat (\%) }\end{array}$ \\
\hline 3 & 14.93 & 8.69 & 58 \\
\hline 4 & 14.94 & 10.08 & 67 \\
\hline 7 & 15.02 & 9.19 & 61 \\
\hline 10 & 14.99 & 7.84 & 52 \\
\hline
\end{tabular}

TABLE VII: ReQuiRed Heat DUty Vs. AVAILABLE HeAT FOR 85\% REMOVAL EFFICIENCY (40\% MEA AND $0.30 \mathrm{CO}_{2}$ LOADING).

\begin{tabular}{|c|c|c|c|}
\hline $\mathrm{CO}_{2}$ concentration (vol\%) & $\begin{array}{c}\text { Required re-boiler } \\
\text { Energy (MW) }\end{array}$ & $\begin{array}{c}\text { Available heat duty } \\
\text { (MW) }\end{array}$ & $\begin{array}{c}\text { Percentage of available } \\
\text { heat }(\%)\end{array}$ \\
\hline 3 & 13.29 & 8.69 & 65 \\
\hline 4 & 13.39 & 10.08 & 75 \\
\hline 7 & 13.6 & 9.19 & 67 \\
\hline 10 & 12.99 & 7.84 & 60 \\
\hline
\end{tabular}

Table VI and VII are representing the available heat as a percentage of required re-boiler duty. It can be clearly seen that, $75 \%$ of energy penalty of case II $\left(4 \% \mathrm{CO}_{2}\right)$ gives the maximum available heat for replacing re-generation process.

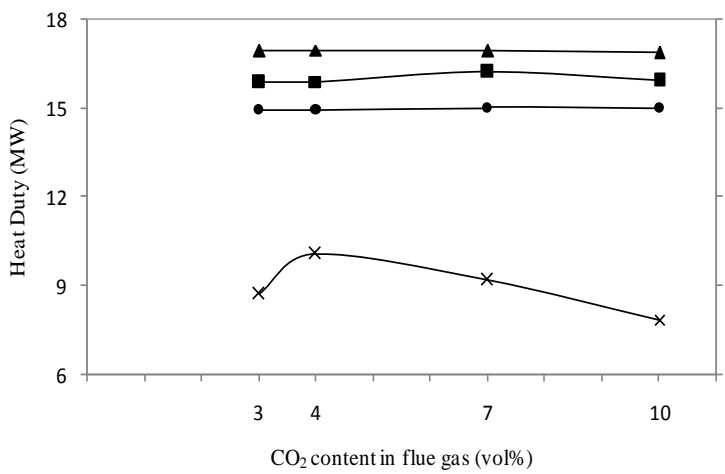

Fig. 16. Available heat duty vs. required re-generation energy for $30 \mathrm{w} / \mathrm{w} \%$ MEA concentration and 0.25 ( $\mathrm{mol} \mathrm{CO} / 2 / \mathrm{mol} \mathrm{MEA} \mathrm{CO}_{2}$ lean loading, symbols refer to : $\mathbf{\Lambda}, 95 \%$ Eff; $\mathbf{- 1}, 90 \%$ Eff; $\bullet, 85 \%$ Eff; ×, Available heat.

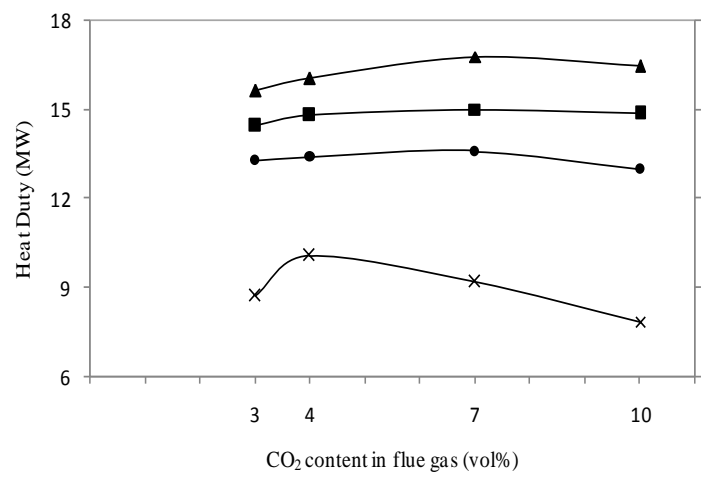

Fig. 17. Available heat duty vs. required re-generation energy for $40 \mathrm{w} / \mathrm{w} \%$ MEA concentration and $0.30(\mathrm{~mol} \mathrm{CO} / 2 \mathrm{~mol} \mathrm{MEA}) \mathrm{CO}_{2}$ lean loading, symbols refer to: $\boldsymbol{\Lambda}, 95 \%$ Eff; $\bullet, 90 \%$ Eff; $\bullet, 85 \%$ Eff; $\times$, Available heat.

\section{CONCLUSION}

The basic idea behind this study is to develop and implement the $\mathrm{CO}_{2}$ capture model for flue gas from aluminium production plant. Several $\mathrm{CO}_{2}$ concentrations, 3, 4, 7 and $10 \mathrm{vol} \%$, in the flue gas from the aluminium production are investigated to find the optimum $\mathrm{CO}_{2}$ content in the flue gas. Finally, according to the simulated results, percentage of optimum $\mathrm{CO}_{2}$ concentration in the flue gas was concluded.
The $\mathrm{CO}_{2}$ loading is varied from $0.15-0.35(\mathrm{~mol} \mathrm{CO} / \mathrm{mol}$ MEA) with MEA concentration $30 \%$ and $40 \%$. Carbon capture models are developed for 3 different efficiencies, $85 \%, 90 \%$ and $95 \%$. The temperature of the flue gas is considered as $9.5^{\circ} \mathrm{C}$ for initial condition and $40^{\circ} \mathrm{C}$ after that.

The MEA concentration $40 \%$ and lean $\mathrm{CO}_{2}$ loading 0.3 give the optimum solvent condition for $\mathrm{CO}_{2}$ capture process. With the removal efficiency, re-boiler duty is increasing and the minimum is given by $85 \%$ removal efficiency. It can be concluded that, specific re-boiler duty for $\mathrm{CO}_{2}$ capture process is increasing with the flue gas temperature. The required re-boiler duties are in the range of $3.0-3.5 \mathrm{MJ} / \mathrm{kg}$ $\mathrm{CO}_{2}$ for $85 \%$ removal efficiency and $3.2-3.5 \mathrm{MJ} / \mathrm{kg} \mathrm{CO}$ for $90 \%$ removal efficiency and $3.4-3.6 \mathrm{MJ} / \mathrm{kg} \mathrm{CO}$ for $95 \%$ removal efficiency. It can be concluded that $10 \% \mathrm{CO}_{2}$ gives highest temperature as $67^{\circ} \mathrm{C}$, and $3 \% \mathrm{CO}_{2}$ gives temperature value as $42^{\circ} \mathrm{C}$. All four cases show the temperature bulge at the top of the column for both liquid and vapor phase. It can be clearly seen that, $75 \%$ of energy requirement of case II ( $4 \%$ $\mathrm{CO}_{2}$ ) gives the maximum available heat for replacing re-generation process. According to the present study, it can be clearly stated that, $4 \% \mathrm{CO}_{2}$ content in the flue gas is given the optimum available heat to replace the re-generation energy. That will save the energy cost for $\mathrm{CO}_{2}$ capture process of the aluminium production process. However, optimum results will vary with the trade-off between capital cost and energy cost.

\section{REFERENCES}

[1] B. Metz, O. R. Davidson, P. R. Bosch, R. Dave, and L. A. Meyer, "Climate change 2007:Mitigation of climate change," in Proc. Contribution of Working Group III to the Fourth Assessment Report of the Intergovernmental Panel on Climate Change, Cambridge University, Cambridge, pp. 2-23, 2007.

[2] M. Wang, A. Lawal, P. Stephenson, J. Sidders, and C. Ramshaw, "Post-combustion $\mathrm{CO}_{2}$ capture with chemical absorption: A state of the art review," Chemical Engineering Research and Design, vol. 89, pp. 1609-1624, 2011.

[3] D. A. Roling and M. Lynch, An Analyst's Outlook for Aluminium Funda-Mentals, Metal Price, and the Value of Equities, Technical report, Platts Aluminium Symposium: Targeting Transparency, 2004.

[4] International Aluminium Institute, "Selection of articles from IAI-Web," Technical report, International Aluminium Institute, Haymarket, London, vol. 32, no. 2, 2004. 
[5] H. Björk and J. Aronsson, "Process Integration and Performance of Chilled Ammonia $\mathrm{CO}_{2}$ Capture Technology," M.Sc Thesis, Department of Energy and Environment, Chalmers University of Technology, 2011.

[6] A. Plus, "Rate Based model of the $\mathrm{CO}_{2}$ capture process by MEA using Aspen Plus," Aspen Technology Inc, Cambridge, MA, USA, 2008.

[7] A. Mohammad, "Carbon dioxide capture from flue gas," Ph.D Thesis, University of Delft, Netherland, 2009.

[8] A. D. Michael, "A model of vapour-liquid equilibria for acid gas-alkanolamine-water systems," PhD Thesis, University of Texas, USA, 1989.

[9] S. Freguia, "Modeling of $\mathrm{CO}_{2}$ removal from Flue Gas with Mono-ethanolamine," Master Thesis, University of Texas, Austin, USA, 2002.

[10] U. S. P. R. Arachchige and M. C. Melaaen, "Selection of Packing Material for Gas Absorption," European Journal of Scientific Research, vol. 87, no. 1, pp. 117-126, 2012.

[11] V. D. Sørhaug, " $\mathrm{CO}_{2}$ capture from aluminium production," M.Sc. Thesis, Telemark University College, 2012

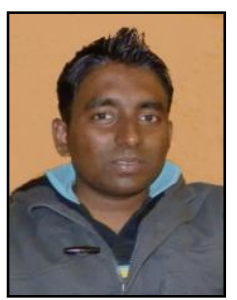

Udara S. P. R. Arachchige received his B.Sc degree in 2007 in chemical and process engineering from University of Moratuwa, Sri Lanka and M.Sc degree in 2010 in energy and environmental engineering from Telemark University College, porsgrunn, Norway.

$\mathrm{He}$ is presently pursuing his $\mathrm{Ph} . \mathrm{D}$ in Carbon dioxide capture from power plants- modeling and simulation studies at Telemark University College. $\mathrm{He}$ has presented and published 14 papers in International Conferences and journals.

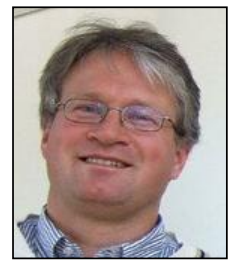

Dinesh Kawan received his B.E degree in 2010 in electronics and communication engineering from Khwopa Engineering College, Purbanchal University, Nepal. $\mathrm{He}$ is presently pursuing his master degree in system and control engineering in Telemark University College, Porsgrunn, Norway.

He also working as a research assistant at faculty of Technology in same university college. Mr. Kawan has research interest on carbon capture, modeling and simulation, and control systems in process industries.

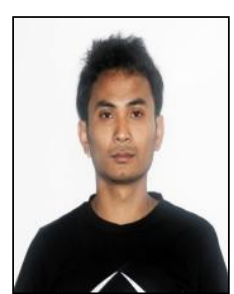

Morten C. Melaaen is a professor in process technology at Telemark University College, Porsgrunn, Norway. He is also the dean of Faculty of Technology, Telemark University College and has a part time position at the local research institute TelTek. Earlier, he has worked as a research engineer in Division of Applied Thermodynamics, SINTEF, Norway and as an associate professor at Norwegian University of Science and Technology (NTNU).

He has worked on research projects as a senior research scientist in Norsk Hydro Research Centre Porsgrunn, Norway. He started to work as a professor at Telemark University College in 1994 and became the head of Department, Department of Process, Energy and Environmental Technology in 2002. He received his MSc in mechanical engineering in 1986 and his Ph.D in 1990, both from NTNU. His research interests are $\mathrm{CO}_{2}$ capture, modeling and simulation, fluid mechanics and heat and mass transfer. Professor Melaaen has more than 100 scientific papers published in the above mentioned related fields in international journals and conferences. 